\title{
Article
}

\section{Trade Credit with Barter in a Capital-Constrained Supply Chain}

\author{
Yangyang Huang ${ }^{1} \mathbb{D}$, Zhenyang $\mathrm{Pi}^{1, * \mathbb{C}}$ and Weiguo Fang $1,2, * \mathbb{C}$ \\ 1 School of Economics and Management, Beihang University, Beijing 100191, China; hyy0208@buaa.edu.cn \\ 2 Key Laboratory of Complex System Analysis, Management and Decision, Beihang University, Ministry of \\ Education, Beijing 100191, China \\ * $\quad$ Correspondence: pzy_1002@buaa.edu.cn (Z.P.); wgfang@buaa.edu.cn (W.F.)
}

check for updates

Citation: Huang, Y.; Pi, Z.; Fang, W.

Trade Credit with Barter in a

Capital-Constrained Supply Chain.

Sustainability 2021, 13, 11361.

https://doi.org/10.3390/su132011361

Academic Editors:

Yoshiki Shimomura and

Shigeru Hosono

Received: 23 September 2021

Accepted: 12 October 2021

Published: 14 October 2021

Publisher's Note: MDPI stays neutral with regard to jurisdictional claims in published maps and institutional affiliations.

Copyright: (c) 2021 by the authors. Licensee MDPI, Basel, Switzerland. This article is an open access article distributed under the terms and conditions of the Creative Commons Attribution (CC BY) license (https:/ / creativecommons.org/licenses/by/ $4.0 /)$.

\begin{abstract}
Barter has emerged to alleviate capital pressure, maximize the circulation of goods, and facilitate the disposal of excess inventory. This study considers a two-level supply chain consisting of a manufacturer and a capital-constrained retailer with trade credit, in which the retailer exchanges unsold products for needed subsidiary products on a barter platform. The retailer's optimal order quantity and the manufacturer's wholesale price are derived, and the influences of barter and other factors on the equilibrium strategy and performance of the supply chain are examined; these results are verified and supplemented by numerical simulation. We find that the retailer can increase profit by bartering when facing highly uncertain demand, that the retailer's optimal order quantity increases with the supply rate and demand for subsidiary products, and that both manufacturer and retailer benefit from the high supply rate of subsidiary products. However, barter induces the manufacturer to raise the wholesale price to prevent its profit from being harmed. In addition, the manufacturer suffers from the retailer's initial capital.
\end{abstract}

Keywords: trade credit; barter; equilibrium strategy; capital constraint

\section{Introduction}

Barter is considered a tool for increasing assets, entering new markets, increasing profits, and creating wealth. Experts estimate that barter trade accounts for one-third of the world's total transactions, and $80 \%$ of Fortune 500 companies are willing to engage in barter exchange (http:/ / www.innovativetravelmarketing.com/pr_intelligentcash.html (accessed on 10 September 2021)). In 2011, the value of annual barter transactions was as high as 120 million USD [1], and 65\% of companies listed on the New York Stock Exchange use barters to clear excess inventory [2]. The reasons for bartering are financial constraints, barter constituting a relatively cheap financing method, and spare capacity, allowing the purchase of what is needed at the carrying cost of the inventory [3]. Barter is popular in society because there is no extra cost. In other words, barter is a direct means of exchange without a medium of exchange, which gives it an important position in modern economies [4].

According to different classification criteria, barters can be divided into different categories. For example, depending on the participant, there are two common types of barter: namely peer-to-peer barter (P2P barter) and business-to-business barter (B2B barter or commercial barter). Fueling the development of B2B, many barter platforms have been built around the world. For example, Jiuwangyihuo (Jiuwangyihuo: https: / /www.jiuwangyihuo.com/ (accessed on 7 September 2021)), Ebarter (Ebarter: http:/ / www.ebarter.cn/ (accessed on 7 September 2021)), and Ewu net (Ewu net: http:/ /www. ewu.cc/ (accessed on 7 September 2021)) are more popular barter platforms in China, while PaperBack Swap (PaperBack Swap: https: / / www.paperbackswap.com/ (accessed on 7 September 2021)), Business Barter Xchange (Business Barter Xchange: https: / www. businessbarterxchange.com/ (accessed on 7 September 2021)), and BarterCard (BarterCard: https:/ / bartercard.com/ (accessed on 7 September 2021)) are common barter platforms 
abroad. Specifically, a company called " $\mathrm{H}$ " posts the necessary information on the barter platform, including what kinds of products and/or services they need and can exchange, what the price is, and how much they need. Another eligible company, " $X$ ", will then conduct a no-money transaction with " $\mathrm{H}$ " on the barter platform. At this point, the platform charges a commission of $5-15 \%$ of the total transaction amount. If Company $X$ does not need the products and/or services provided by Company $\mathrm{H}$, other companies in the barter pool will participate in the transaction. Such multilateral bartering has a circular structure [5]; that is, the barter is a relatively closed economic form. Compared with the traditional economy, the price of the barter transaction is the same as the sales price, so price discounts are not commonly considered [2].

From the above description, we note that barters have many benefits, including eliminating the inventory pressure of surplus goods, making full use of capacity, and coping with random demand. As enterprises do not need working capital to obtain what they need to maintain normal operational management under this practice, an increasing number of companies have engaged in bartering.

Many companies face serious operational problems caused by a lack of capital. Moreover, capital constraints make it difficult for them to achieve an optimal order quantity or production quantity based on the estimated market demand. If a company's cash flow is interrupted for a long time, supply and demand in the market will not reach an equilibrium state, resulting in violent price fluctuations. Therefore, companies with capital constraints seek financing to maintain normal production and operational activities. For supply chain members, the ways to seek financial support can be roughly divided into two basic modes: external financing and internal financing. A loan from a bank belongs to external financing, while trade credit belongs to internal financing. Generally, companies' first consideration is to obtain loans from banks or other financial institutions through external financing. However, companies often encounter difficulties in obtaining loans due to credit risks and high demand/supply risks, especially emerging companies, fast-growing companies in developing economies [6], and Small and Medium Enterprises (SMEs). Supply chain internal financing arose to resolve this problem, enabling companies to mitigate capital shortage by developing trade credit contracts between supply chain members $[7,8]$. The value of trade credit extended to non-financial companies in the United States is about 4.5 trillion USD, equivalent to $21 \%$ of US GDP in 2019 [9]. Thus, trade credit is a common and important short-term financing tool.

Barter exists in established economies and operates in parallel with monetary systems (https://www.accaglobal.com/in/en/business-finance/types-finance/bartering.html (accessed on 10 October 2021)). In addition to clearing excess inventories, barter can be an important complement to bank loans and trade credits that ease financial pressure. Meanwhile, large enterprises are willing to offer or accept trade credit contracts. In practice, both barter and trade credit have been widely adopted by many large enterprises and capitalconstrained SEMs. Although many firms are engaged in barter and trade credit, the effect of barter on trade credit contracts has not been studied. Therefore, we sought to determine the impact of barter and other factors on supply chain operations under trade credit. In this study, we focus only on commercial barters. Through theoretical analysis and numerical simulation, we demonstrate that barters are more advantageous to the supply chain in the case of a high supply rate and high demand for subsidiary products, low customer demand volatility, and lower retailer initial capital. We show that barter encourages retailer orders, and the optimal order quantity increases with the supply rate and demand for subsidiary products on the barter platform. The supply chain benefits from the supply rate of subsidiary products, although the manufacturer suffers from the retailer's initial capital, and the barter induces the manufacturer to raise the wholesale price.

The remainder of this paper is organized as follows. Section 2 briefly reviews the related literature on barter exchange and trade credit. In Section 3, we describe the scenario of the problem under study. Section 4 derives the equilibrium strategies of supply chain members. We reveal the influences of barter and other factors on the equilibrium strategy 
and the performance of the supply chain by numerical simulation in Section 5. Finally, we conclude this paper and provide suggestions for future research in Section 6. Additional proofs are provided in Appendix A.

\section{Literature Review}

This study explores the impact of barter exchange on supply chains in the presence of trade credit. Therefore, our work is related to two streams of literature: barter exchange and trade credit.

\subsection{Barter Exchange}

Barter exchange, as a common business model, is becoming increasingly popular in every aspect of business [2]. In fact, barter exchange dates back to early primitive societies, when consumers could barter for any good or service they wanted. In recent years, barter exchange has mainly been adopted by SMEs [10]. Due to its universality and popularity, some studies have focused on the influence of barters on the supply chain. For example, Plank et al., (1994) found that barters have advantages in reducing overall inventory costs [10]. Erridge and Zhabykenov (1998) demonstrated the contribution of counter-trade to procurement based on empirical research [11]. Guriev and Kvassov (2004) found that barters may be used as a price discrimination instrument in asymmetric information markets [3]. Hua et al., (2020) used barter to explain the newsvendor problem, showing that barter allowed a better response to uncertain demands [2]. Zhang et al., (2020) studied the influence of barter on supply chain performance under pull contracts and considered the decision bias of supply chain members on the supply rate of subsidiary products of barter platforms. They found that retailer underestimation improved supply chain performance [12].

In addition, some studies have explored the criteria of barter exchange. Marin and Schnitzer (2002) pointed out that barters could relieve the debt pressure of high-debt countries [13]. Noguera and Linz (2006) developed a model that showed that barters can be considered to be a means of improving social welfare and responding to tight monetary policy [14]. Mpinganjira (2011) studied the relationship between barter and the initiative of media companies in South Africa to participate in barter activities, finding that the lower the initiative, the higher the difficulty perceived by media companies [15]. Melis and Guidici (2014) explained the economic effect of barters on easing capitalist economic crises [16]. Anderson et al., (2017) considered matching demand dynamically to improve the efficiency of the random barter market [5]. Ye et al., (2018) conducted an empirical study on the P2P online book barter market and concluded that an increase in the interaction frequency of participants improves barter efficiency [17]. Fujishige and Yang (2021) explained the reasons for the widespread existence of barter markets with an improved Markovian core [18].

In contrast to previous studies, this study considers the barter application scenario with delayed payment and derives the optimal order quantity and optimal wholesale price in this scenario.

\subsection{Trade Credit}

Many scholars have studied trade credit, which has been widely used in supply chain management. Lee and Stowe (1993) explained that a manufacturer can signal to the retailer through trade credit contracts that their products are of more competitive quality [19]. Liao et al., (2000) developed a delayed payment model that showed that retailers would order more because of lower costs [20]. Summers and Wilson (2003) argued that trade credit could promote the growth of frequent customers or large customers [21]. Gupta and Wang (2009) pointed out that under random demand, a retailer's optimal order strategy could not be affected by trade credit [22]. Giannetti et al., (2011) found that trade credit is a means of price discrimination [23]. Chen and Wang (2012) examined the impact of trade credit on a two-level supply chain under budget constraints. They found that trade credit contracts 
can coordinate supply chains with budget constraints to create value [24]. Klapper (2012) found that buyers with good reputations or large scales usually have an advantage in trade credit because they possess higher bargaining power [25]. Luo and Zhang (2012) found that trade credit can facilitate supply chain coordination under symmetric information rather than asymmetric information, even though the buyer can improve its profit [26]. Zhong and Zhou (2013) constructed a performance improvement model that can improve the profitability of supply chain members under trade credit [27]. Zhang et al., (2014) determined that manufacturers would limit product supply when providing trade credit. Simultaneously, to coordinate the supply chain, they proposed a revised quantity discount contract [28]. Moreover, Dass et al., (2015) found that trade credit contracts can effectively prevent the delivery of substandard products, thus protecting retailers' profits [29]. Chen and $\mathrm{Yu}(2017)$ argued that trade credit is a useful tool for stabilizing wholesale prices in the context of oversupply [30]. Phan et al., (2019) proposed that trade credit contracts based on risk compensation make it easier to adjust capital-constrained supply chains (CCSC) [7]. Yang et al., (2019) considered that a retailer with scarce funds will order more products, while a wealthy retailer will do the opposite in a capital-constrained supply chain [8]. Yang et al., (2021) found that risk-averse suppliers and capital-constrained retailers could benefit from trade credit [31]. Wang et al., (2021) showed that a trade credit contract can replace the price contract in certain situations by comparing credit contracts with price contracts [32].

On the other hand, some studies have investigated the role of trade credit in finance. Ferrando and Mulier (2013) showed that SMEs are more dependent on trade credit to achieve profit growth and reduce the impact of financial market fluctuations [33]. Devalkar and Krishnan (2019) indicated that financial frictions increased financing costs and weakened the ability of trade credit to coordinate supply chains [34]. Liu et al., (2020) considered that an advantaged buyer benefits from trade credit in the market. Furthermore, political relations have a positive impact on trade credit [35].

In this study, we extend previous research by considering how supply chain members increase their profits through barter platforms under trade credit, and in particular, how retailers reduce costs.

\section{Problem Description}

Based on the selling-to-the-newsvendor model, we consider a two-level supply chain consisting of a manufacturer (referred to as "he") and a retailer (referred to as "she") with capital constraints. The demand $X$ is stochastic, with a cumulative distribution function (CDF) $F(X)$ and probability density function (PDF) $f(X)$. Referring to existing work on supply chain management [36], we assume that the general failure rate, $H(X)=X h(X)=\frac{X f(X)}{\bar{F}(X)}$, is increasing in $X$. Let $Q$ be the order quantity of the retailer to satisfy the stochastic demand. Let $p, w, c$, and $s$ be the retail price, wholesale price, production cost, and salvage value of the product, respectively. It is straightforward to assume that $p>w>c>s$. If the above constraints are not met, the manufacturer will not produce the product and the retailer will not enter the market.

In addition to selling products, the retailer also needs to buy certain subsidiary products from the market, such as office supplies, for her daily operations. Barter transactions must be based on the principle of equal value exchange; that is, if the retailer wants to obtain subsidiary products of value $V$ from the barter platform, she must offer products of equal value that she sells to the platform for exchange. To simplify the analysis, we assume that the total value of subsidiary products obtained by the retailer is $p Q_{0}$, which can be regarded as the cost that the retailer should pay to the barter platform [2]. $Q_{0}$ can be understood as an equivalent product quantity; that is, the value of the subsidiary products required by the retailer on the barter platform is equal to the value of $Q_{0}$ units of self-sold products. Selling the products must be profitable for the retailer-that is, $(p-w) Q-p Q_{0} \geq 0$; otherwise, she will not join the game. Newsvendor-like retailers have limited initial capital $B$. It is reasonable for the retailer's initial capital to at least cover the cost of the subsidiary product; that is, $B \geq p Q_{0}$. To ease capital constraints, the manufacturer offers a trade credit 
contract to the retailer, in which the retailer pays the procurement cost using her available working capital and then pays the rest at the end of the selling season. In this setting, the retailer holds $p Q_{0}$ cash for her subsidiary products when sales begin. Accordingly, the loan obligation for trade credit is $L=w Q-\left(B-p Q_{0}\right)=w Q+p Q_{0}-B$.

To eliminate excess inventory, the retailer can barter subsidiary products on the platform. Assume that the retailer will pay a commission $r p(r \geq 0)$ to the platform for each unit of the product exchanged. Intuitively, $r$ cannot be too high; otherwise, it is not profitable for the retailer to barter on the platform. Suppose that $p-r p>s$ - that is, $r<1-\frac{s}{p}$ - to ensure that the retailer obtains positive profits by bartering. In practice, $r$ is usually $0.05-0.15$ [2]. However, the supply of subsidiary products on the platform may be limited. For simplicity, let $\alpha Q_{0}$ be the supply available of subsidiary products, where $\alpha \geq 0$; that is, the retailer exchanges her self-sold products for subsidiary products only in at most $\alpha Q_{0}$ units. It should be noted that when $\alpha>1$, the subsidiary product supply is sufficient and has no impact on the retailer's transaction on the platform. This means that the problem with $\alpha>1$ is the same as that with $\alpha=1$. Therefore, in the following discussion, we focus only on the scenario with $0 \leq \alpha \leq 1$.

It can be seen intuitively that when the demand realization and/or supply of subsidiary products is relatively low, the retailer's revenue, $\Gamma$, is relatively low and cannot bear trade credit obligations (i.e., $\Gamma<L$ ). Consequently, the retailer files for bankruptcy, and the manufacturer collects the retailer's revenue. Assume that there exists a bankruptcy costthat is, the manufacturer can only obtain $\eta \Gamma(0 \leq \eta \leq 1)$-following earlier studies [37].

In this study, we focus on a Stackelberg game between the retailer and manufacturer. The manufacturer, as the Stackelberg leader, first sets the wholesale price $w$. The retailer then acts as a follower, placing an order with the manufacturer for quantity $Q$ and then selling the products to the consumer at a fixed retail price $p$. The key sequences of the events and decisions are as follows:

(i) The manufacturer establishes a trade credit contract with the retailer at the wholesale price w;

(ii) The retailer decides the order quantity $Q$ and pays her initial capital $B$ to the manufacturer;

(iii) The retailer sells products to the end customers. When customer demand is less than the order quantity (i.e., $x<Q$ ), the retailer trades unsold products on the barter platform in exchange for the subsidiary products that she needs. Subsequently, salvage values are generated for the unsold products. We do not consider the impact of demand exceeding the order quantity (i.e., $x \geq Q$ ) on the retailer;

(iv) The retailer pays off debts to the manufacturer or goes bankrupt. The manufacturer then receives the remaining payment or collects the retailer's revenue.

Figure 1 shows a summary of the event timeline, where $\mathrm{M}$ and $\mathrm{R}$ are used to represent the manufacturer and retailer, respectively.

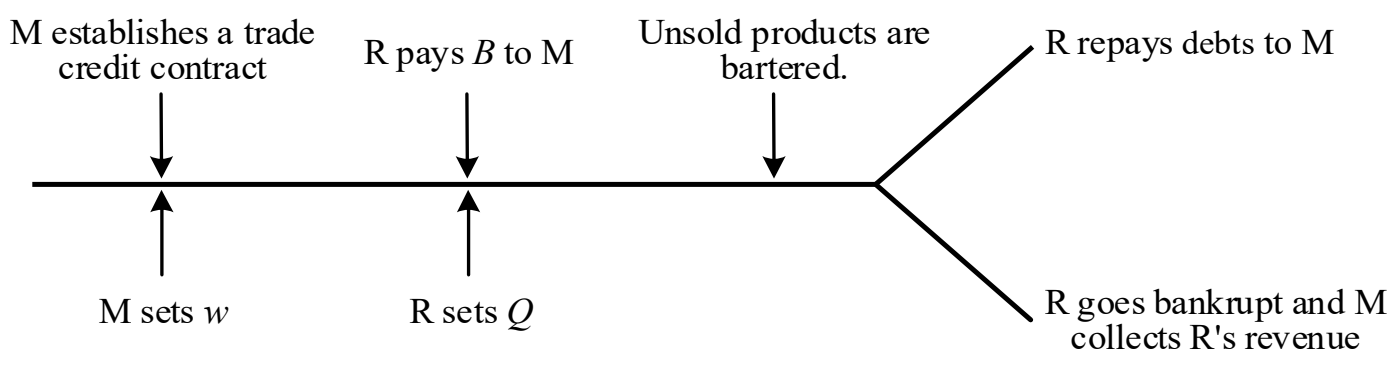

Figure 1. Timeline of events.

Key notations are presented in Table 1. 
Table 1. Key notations.

\begin{tabular}{cc}
\hline Notation & Definition \\
\hline$i$ & Index of supply chain member, $i=\{r, m\}$ \\
$X$ & Stochastic demand \\
$x$ & Realization of demand \\
$F(X)$ & Cumulative distribution function of $x$ \\
$f(X)$ & Probability density function of $x$ \\
$Q$ & Retailer's order quantity \\
$p$ & Retail price \\
$w$ & Wholesale price \\
$c$ & Production cost \\
$s$ & Salvage value \\
$Q_{0}$ & Equivalent product quantity to subsidiary products \\
$B$ & Retailer's initial capital \\
$L$ & Trade credit loan obligation \\
$r$ & Commission rate \\
$\alpha$ & Supply rate offered by platform \\
$\Gamma$ & Retailer's revenue \\
$\eta$ & Rate of bankruptcy cost \\
$\pi_{i}$ & Profit of supply chain member $i$ \\
$\Pi_{i}$ & Expected profit of supply chain member $i$ \\
\hline
\end{tabular}

\section{Equilibrium Strategies under Barter}

In this section, we explore how trade credit interacts with barter exchange in a twolevel supply chain. The backward induction method is adopted to examine the equilibrium strategies. Specifically, we first explore the retailer's optimal order quantity response function. Then, we derive the equilibrium wholesale price for the manufacturer.

\subsection{The Retailer's Problem: Optimal Order Quantity}

Before deriving the optimal order strategy, we first obtain the retailer's profit, which mainly depends on demand realization. With $p Q_{0}$ cash on hand to cover the cost of subsidiary products, the retailer's profit equals her sales revenue plus the salvage of $p Q_{0}$ after paying for the subsidiary products, then minus the trade credit obligations, and again minus her initial capital B. Specifically,

(i) When demand realization is high-that is, $x \geq Q$-all products are sold out and the retailer must buy subsidiary products using her cash $p Q_{0}$. Therefore, the retailer's profit is

$$
\pi_{r}=\left(p Q_{0}+p Q-L-p Q_{0}\right)^{+}-B=p Q-L-B
$$

(ii) When the demand realization is medium-that is, $Q-\alpha Q_{0} \leq x<Q$-the retailer can exchange $Q-x$ units of products on the barter platform for subsidiary products and buy $Q_{0}-(Q-x)$ units of subsidiary products outside. Therefore, the retailer's profit is

$$
\begin{aligned}
\pi_{r} & =\left(p Q_{0}+p x-r p(Q-x)-p\left(Q_{0}-(Q-x)\right)-L\right)^{+}-B \\
& =(r p x+(1-r) p Q-L)^{+}-B
\end{aligned}
$$

Since $x \geq Q-\alpha Q_{0}$ and $(1-r) p \geq s$, it is easy to verify that

$$
\pi_{r}=r p x+(1-r) p Q-L-B
$$

(iii) When the demand realization is relatively low-that is, $x<Q-\alpha Q_{0}$ 一the retailer exchanges $\alpha Q_{0}$ units of products on the barter platform for subsidiary products, 
salvages the remaining $Q-\alpha Q_{0}-x$ units of products, and buys $(1-\alpha) p Q_{0}$ units of subsidiary products. Accordingly, the retailer's profit is

$$
\begin{aligned}
\pi_{r} & =\left(p Q_{0}+p x-r p \alpha Q_{0}+s\left(Q-\alpha Q_{0}-x\right)-(1-\alpha) p Q_{0}-L\right)^{+}-B \\
& =\left((p-s) x+s Q+\alpha((1-r) p-s) Q_{0}-L\right)^{+}-B
\end{aligned}
$$

There exists a bankruptcy threshold $\underline{x}$, which satisfies

$$
(p-s) x+s Q+\alpha((1-r) p-s) Q_{0}-L=0,
$$

i.e., $\underline{x}=\frac{L-s Q-\alpha((1-r) p-s) Q_{0}}{p-s}$.

Accordingly, the retailer's profit is

$$
\pi_{r}=\left\{\begin{array}{l}
(p-s) x+s Q+\alpha((1-r) p-s) Q_{0}-L-B \text { if } x \geq \underline{x} \\
-B \text { if } x<\underline{x}
\end{array}\right.
$$

Summarizing Equations (1)-(3), we can collect the retailer's profit with respect to different demand realizations as follows:

$$
\pi_{r}=\left\{\begin{array}{l}
p Q-L-B \text { if } x \geq Q \\
r p x+(1-r) p Q-L-B \text { if } Q-\alpha Q_{0} \leq x<Q \\
(p-s) x+s Q+\alpha((1-r) p-s) Q_{0}-L-B \text { if } \underline{x} \leq x<Q-\alpha Q_{0} \\
-B \text { if } x<\underline{x}
\end{array}\right.
$$

Thus, according to Equation (4), we obtain the retailer's expected profit:

$$
\mathbf{E} \pi_{r}=(p-w) Q-p Q_{0}-r p \int_{Q-\alpha Q_{0}}^{Q} F(x) d x-(p-s) \int_{\underline{x}}^{Q-\alpha Q_{0}} F(x) d x
$$

It can be seen from Equation (5) that barter exchange has an impact on the retailer's expected profit. The following proposition gives the retailer an optimal order quantity:

Proposition 1. Under trade credit, the retailer's optimal order quantity with barter exchange, $Q^{*}$, is determined by

$$
r p \bar{F}(Q)+((1-r) p-s) \bar{F}\left(Q-\alpha Q_{0}\right)-(w-s) \bar{F}(\underline{x})=0
$$

When $Q_{0}=0$ or $\alpha=0$, Equation (6) reduces to

$$
(p-s) \bar{F}(Q)-(w-s) \bar{F}(\underline{x})=0 .
$$

When $\underline{x}=0$, Equation (6) reduces to

$$
r p \bar{F}(Q)+((1-r) p-s) \bar{F}\left(Q-Q_{0}\right)-(w-s)=0 .
$$

According to Equation (6), the optimal order quantity $Q^{*}$ is affected by multiple factors, such as the commission rate and supply rate. In particular, in Equation (7), we obtain the optimal order quantity when subsidiary products are not needed or when the retailer does not barter. Similarly, Equation (8) gives the optimal order quantity if the retailer is not bankrupt. Based on Proposition 1, we draw the following corollary.

Corollary 1. Under trade credit, the retailer's optimal order quantity with barter exchange is increasing in both $\alpha$ and $Q_{0}$.

Corollary 1 shows that the higher the supply rate of subsidiary products, the higher the demand for subsidiary products; the retailer will then order more products, inducing the manufacturer to produce more products. When the retailer can barter for a certain 
number of unsold products for more subsidiary products, she orders more products from the manufacturer. This is because she can save some expenses on fixed assets. Similarly, when the demand for subsidiary products is high, the retailer will make the same decision because she does not need to spend extra cash to buy subsidiary products. In general, the retailer can benefit from bartering.

\subsection{The Manufacturer's Problem: Optimal Wholesale Price}

The manufacturer's profit is

$$
\pi_{m}=\left\{\begin{array}{l}
B-p Q_{0}+L-c Q \text { if } x \geq \underline{x} \\
B-p Q_{0}+\eta\left((p-s) x+s Q+\alpha((1-r) p-s) Q_{0}\right)-c Q \text { if } x<\underline{x}
\end{array}\right.
$$

According to Equation (9), the manufacturer's expected profit is

$$
\mathbf{E} \pi_{m}=(w-c) Q-(1-\eta) L F(\underline{x})-\eta(p-s) \int_{0}^{\underline{x}} F(x) d x
$$

According to Equation (10), it is obvious that the barter has an impact on the manufacturer's expected profit. The following proposition gives the optimal wholesale price under trade credit:

Proposition 2. Under trade credit, the optimal wholesale price of the manufacturer is determined by

$$
\frac{\Re_{1}-\Re_{2}}{1-\frac{w-s}{p-s} Q h(\underline{x})}-c+s \eta=0,
$$

where

$$
\begin{gathered}
\Re_{1}=\bar{F}(\underline{x})\left(w-\eta s-\frac{w-s}{p-s}(1-\eta)(L+s Q) h(\underline{x})\right), \\
\Re_{2}=Q\left(1-\frac{1-\eta}{p-s} \operatorname{Lh}(\underline{x})\right)\left(r p f(Q)+((1-r) p-s) f\left(Q-\alpha Q_{0}\right)\right) .
\end{gathered}
$$

The manufacturer, the leader of the Stackelberg game, can set the wholesale price according to the retailer's orders. According to Equation (11), barter changes the optimal wholesale price structure of the traditional newsvendor model. When the retailer is doing well-that is, not bankrupt (i.e., $\underline{x}=0)$-Equation (11) reduces to $r p f(Q)+((1-r) p-s) f\left(Q-\alpha Q_{0}\right)=\frac{w-c}{Q}$. Therefore, the manufacturer will also consider the influence of barter exchange (i.e., $r$ and $\alpha$ when setting the wholesale price.

\section{Numerical Simulation}

In this section, we carry out a numerical simulation to illustrate the impact of barter exchange on the equilibrium strategy and performance of the supply chain. It should be pointed out that the parameter setting is based on many experiments, meets the assumptions in the model, and is consistent with existing literature [12,38].

First, we examine the impact of supply rate $\alpha$ and demand uncertainty $\sigma$ on supply chain equilibrium strategy and profit. Referring to earlier studies $[10,38]$, we assume that the stochastic demand satisfies a normal distribution; that is, $X \sim N\left(\mu, \sigma^{2}\right)$ with $\mu=100$. In addition, we set the retail price $p=8$, production $\operatorname{cost} c=4$, salvage value $s=2$, initial capital $B=80$, equivalent product quantity $Q_{0}=2$, commission rate $r=0.1$, and rate of bankruptcy cost $\eta=0.8$. Figure 2 shows the impact of $\alpha$ and $\sigma$ on the supply chain equilibrium strategy and profit. 


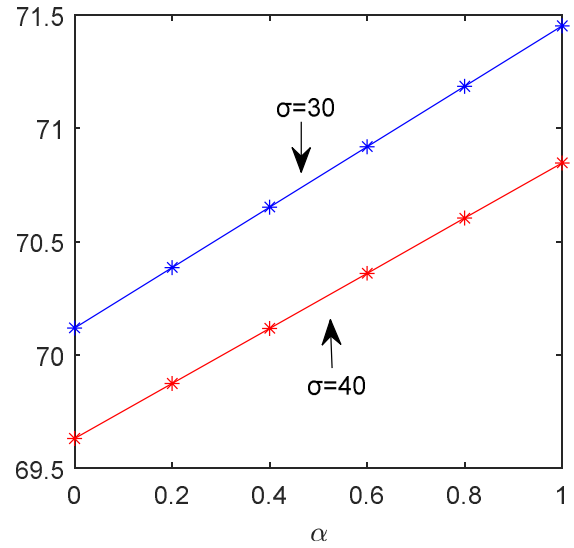

(a) Order quantity

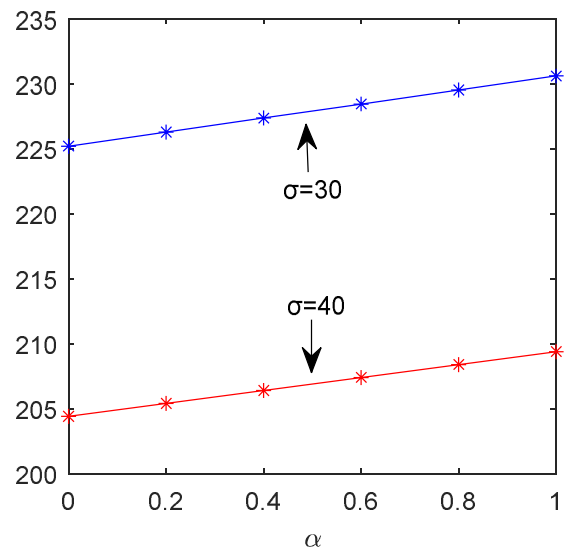

(c) Manufacturer's expected profit

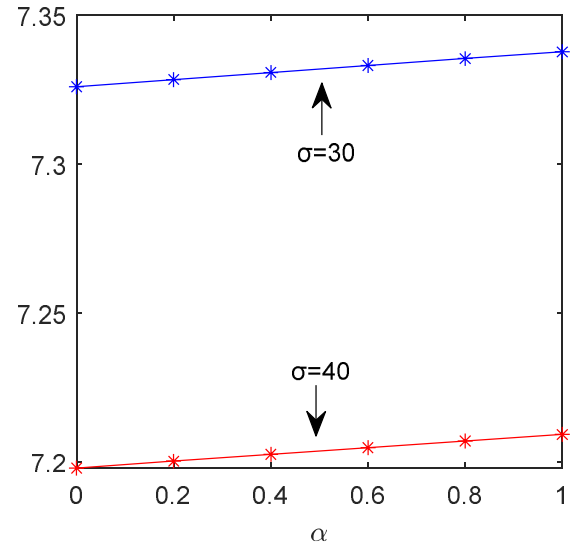

(b) Wholesale price

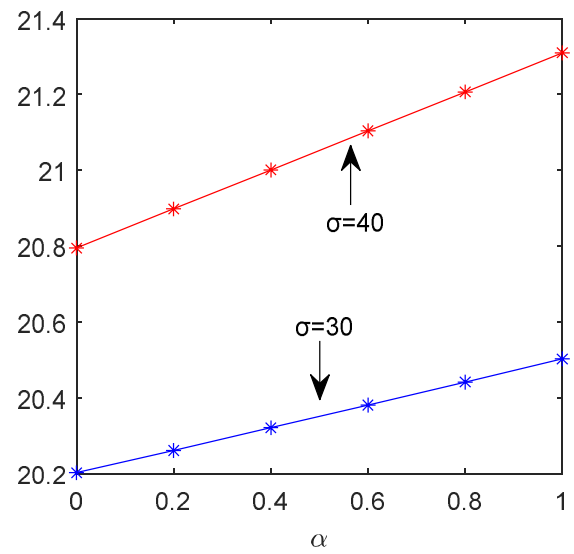

(d) Retailer's expected profit

Figure 2. Impact of $\alpha$ and $\sigma$ on equilibrium strategy and profit.

As shown in Figure 2a, the more volatile the demand, the less the retailer orders, thus reducing the inventory risk. However, when the supply rate of the barter platform is high, the retailer orders more products, because she can trade in unsold products for subsidiary products. The wholesale price increases with the supply rate and decreases with demand uncertainty, as shown in Figure 2b. Faced with lower wholesale prices, the retailer is unable to make a positive order plan because of the commission charged by the platform. It can be seen from Figure $2 c, d$ that with the increase in supply rate, the expected profits of both the manufacturer and retailer will increase, while the impact of demand volatility on their expected profits will be reversed. In other words, supply chain members will benefit from barter-especially the retailer, who will benefit more because demand fluctuates more. The retailer can sense changes in consumer demand and benefit from the deferred payment offered by the manufacturer, which allows her to trade unsold products without money for more subsidiary products.

Next, we examine the impact of the retailer's initial capital $B$ and equivalent product quantity on subsidiary products, $Q_{0}$, on equilibrium strategy and profit with the following parameter settings: the stochastic demand $X \sim N\left(100,30^{2}\right), p=8, c=3, s=2, r=0.15$, $\alpha=0.8$, and $\eta=0.8$. Figure 3 shows the impact of $B$ and $Q_{0}$ on the supply chain equilibrium strategy and profit. 


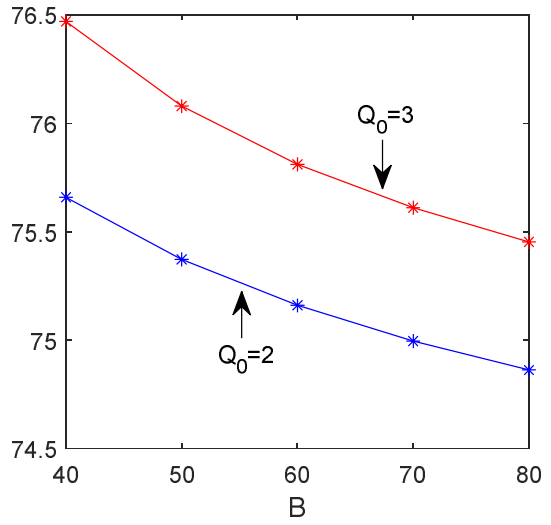

(a) Order quantity

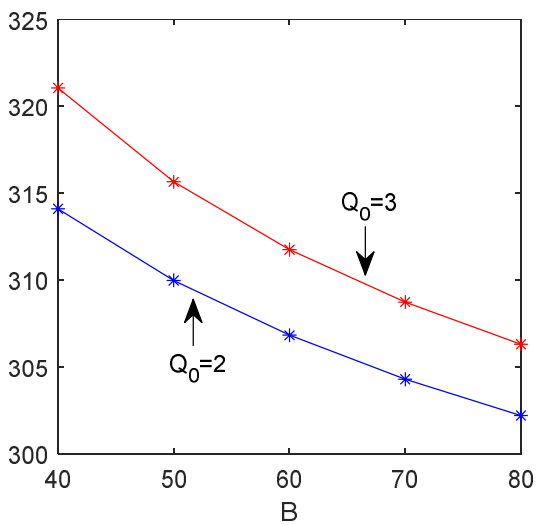

(c) Manufacturer's expected profit

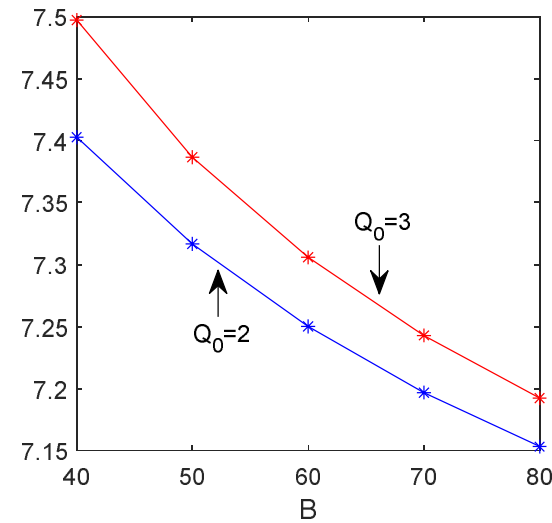

(b) Wholesale price

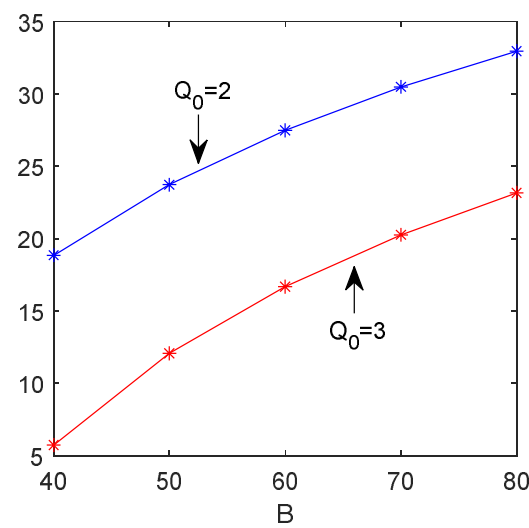

(d) Retailer's expected profit

Figure 3. Impact of $B$ and $Q_{0}$ on equilibrium strategy and profit.

The retailer's initial capital has a negative impact on equilibrium strategies (Figure 3a,b) and the manufacturer's expected profit (Figure 3c). However, the retailer's expected profit increases with $B$ (Figure $3 \mathrm{~d}$ ). This means that the retailer has more initial capital to sustain herself, reducing the probability of bankruptcy. The manufacturer is also willing to believe that the retailer is rich and offers her a lower wholesale price, even if his profit is harmed by bartering. As shown in Figure $3 a, b$, the larger $Q_{0}$ is, the higher the wholesale price will be, and the more the retailer will order. The reason is that the larger $Q_{0}$ is, the more unsold products the retailer can exchange for subsidiary products without having to pay money. This induces the manufacturer to set higher wholesale prices because he realizes that the retailer must order more to save costs. The commission charged by the barter platform is also a cost, and naturally the retailer's expected profit declines when the subsidiary products are in high demand.

\section{Conclusions}

In developing economies, due to credit risks, most SMEs have difficulty obtaining financing and loans from banks [39]. Therefore, the internal financing of the supply chain has emerged as an attempt to solve this problem. With the rapid development of barter exchanges, an increasing number of enterprises are disposing of their unsold goods on barter platforms, which constitutes a strategy of growth and flexibility for SMEs [40]. However, the managerial issues related to capital-constrained retailers in the context of barter exchange have not been fully explored. To remedy the above defects, this study builds a newsvendor model combined with barter exchange under trade credit to reveal the equilibrium strategies of the supply chain.

We find that barter encourages the retailer to order more goods and benefits them. The retailer's optimal order quantity increases with the supply rate and number of subsidiary 
products on the barter platform but decreases with demand volatility and the retailer's initial capital. Therefore, barter is more advantageous to the supply chain when the supply rate is high, the demand for subsidiary products is high, the customer's demand volatility is low, and the retailer's initial capital is less. A retailer can at least learn the following from our study: (1) through a barter platform, the retailer can decide how many products to order from the manufacturer to reduce inventory, especially in the face of high uncertain demand and less initial capital; and (2) the retailer can mitigate the lack of funds by bartering, especially when there is a high demand for subsidiary products. In practice, the retailer should order more products because unsold products can be exchanged on barter platform. This allows the retailer to save money spent on subsidiary products. It is worth noting, however, that barter causes the manufacturer to raise the wholesale price in order to prevent their profit from being harmed.

There are several directions for future research. First, this study only considers deferred payment, so a natural extension is that the manufacturer could require full payment when the retailer places an order. An interesting research direction would be to explore the influence of barter under prepayment on supply chain equilibrium strategy and performance. Next, we may extend the current two-level supply chain consisting of a single manufacturer and a single retailer to a multi-level or multi-entity supply chain on a barter platform. For example, in a three-level supply chain consisting of a supplier, a manufacturer, and a retailer, both manufacturer and retailer can participate in barter. The manufacturer may have excess inventory, including excess raw materials and finished goods, due to uncertainty in lead times, demand, or supply. The manufacturer can exchange excess inventory for needed ancillary products through a barter platform. Therefore, it is an important direction to develop a new analytical model to examine the interaction between barter and trade credit in multi-level supply chain. Finally, it is meaningful to explore the impact of information asymmetry on barter by considering the risk preferences of the manufacturer and/or retailer.

Author Contributions: Investigation, Y.H. and Z.P.; Methodology, Y.H.; Project administration, W.F.; Writing-original draft, Y.H.; Writing-review and editing, Z.P. and W.F. All authors have read and agreed to the published version of the manuscript.

Funding: This paper was supported by the National Natural Science Foundation of China (Grant No. 71901010).

Institutional Review Board Statement: Not applicable.

Informed Consent Statement: Not applicable.

Data Availability Statement: Not applicable.

Conflicts of Interest: The authors declare no conflict of interest.

\section{Appendix A}

Proof of Proposition 1. The first derivative of Equation (5) with regard to $Q$ is

$$
\begin{aligned}
\frac{\partial \mathrm{E} \pi_{r}}{\partial Q} & =\int_{\underline{x}}^{Q-\alpha Q_{0}}(s-w) f(X) d X+\int_{Q-\alpha Q_{0}}^{Q}((1-r) p-w) f(X) d X+\int_{Q}^{+\infty}(p-w) f(X) d X \\
& =\int_{\underline{x}}^{Q}-\alpha Q_{0} s f(X) d X+\int_{Q-\alpha Q_{0}}^{Q}((1-r) p) f(X) d X+\int_{Q}^{+\infty} p f(X) d X-\int_{\underline{x}}^{+\infty} w f(X) d X \\
& =s\left(F\left(Q-\alpha Q_{0}\right)-F(\underline{x})\right)+(1-r) p\left(F(Q)-F\left(Q-\alpha Q_{0}\right)\right)+p(1-F(\bar{Q}))-w(1-F(\underline{x})) \\
& =r p \bar{F}(Q)+((1-r) p-s) \bar{F}\left(Q-\alpha Q_{0}\right)-(w-s) \bar{F}(\underline{x})
\end{aligned}
$$

The second derivative is

$$
\frac{\partial^{2} \mathbf{E} \pi_{r}}{\partial Q^{2}}=\frac{(w-s)^{2}}{p-s} f(\underline{x})-((1-r) p-s) f\left(Q-\alpha Q_{0}\right)-r p f(Q) .
$$


Since $p>w$ and $Q-\alpha Q_{0}>\underline{x}$, we obtain

$$
\begin{aligned}
\frac{\partial^{2} \mathbf{E} \pi_{r}}{\partial Q^{2}}= & \frac{(w-s)^{2}}{p-s} f(\underline{x})-r p f(Q)-((1-r) p-s) f\left(Q-\alpha Q_{0}\right) \\
& <(p-s) f(\underline{x})-r p f(Q)-((1-r) p-s) f\left(Q-\alpha Q_{0}\right) \\
& <(p-s) f(\underline{x})-(p-s) f\left(Q-\alpha Q_{0}\right) \\
& <0
\end{aligned}
$$

Therefore, the optimal order quantity $Q^{*}$ must satisfy the stationary condition; i.e.,

$$
r p \bar{F}(Q)+((1-r) p-s) \bar{F}\left(Q-\alpha Q_{0}\right)-(w-s) \bar{F}(\underline{x})=0 .
$$

Proof of Corollary 1. Applying the implicit function theorem, the first derivative of Equation (6) with regard to $\alpha$ is

$$
-r p f(Q) \frac{\partial Q}{\partial \alpha}-((1-r) p-s) f\left(Q-\alpha Q_{0}\right)\left(\frac{\partial Q}{\partial \alpha}-Q_{0}\right)+(w-s) f(\underline{x}) \frac{\partial \underline{x}}{\partial \alpha}=0 .
$$

Plugging $\frac{\partial \underline{x}}{\partial \alpha}=\frac{(w-s) \frac{\partial Q}{\partial \alpha}-((1-r) p-s) Q_{0}}{p-s}$ into the equation above, and after some simple derivation, we obtain

$$
\frac{\partial Q}{\partial \alpha}=\frac{((1-r) p-s) Q_{0}\left(\frac{w-s}{p-s} f(\underline{x})-f\left(Q-\alpha Q_{0}\right)\right)}{\frac{(w-s)^{2}}{p-s} f(\underline{x})-r p f(Q)-((1-r) p-s) f\left(Q-\alpha Q_{0}\right)} .
$$

This can be rewritten as

$$
\frac{\partial Q}{\partial \alpha}=\frac{((1-r) p-s) Q_{0} \bar{F}(\underline{x})\left(\frac{w-s}{p-s} h(\underline{x})-\frac{f\left(Q-\alpha Q_{0}\right)}{\bar{F}(\underline{x})}\right)}{\frac{(w-s)^{2}}{p-s} f(\underline{x})-r p f(Q)-((1-r) p-s) f\left(Q-\alpha Q_{0}\right)} .
$$

Recall $\frac{(w-s)^{2}}{p-s} f(\underline{x})-r p f(Q)-((1-r) p-s) f\left(Q-\alpha Q_{0}\right)<0$, so to prove $\frac{\partial Q}{\partial \alpha}>0$, we only need to prove

$$
\frac{w-s}{p-s} h(\underline{x})-\frac{f\left(Q-\alpha Q_{0}\right)}{\bar{F}(\underline{x})}<0 .
$$

Recalling that $\underline{x}<Q-\alpha Q_{0}$ and the property of IFR, we have

$$
h(\underline{x})<h\left(Q-\alpha Q_{0}\right)=\frac{f\left(Q-\alpha Q_{0}\right)}{\bar{F}\left(Q-\alpha Q_{0}\right)} .
$$

Therefore, it is sufficient to demonstrate

$$
\frac{f\left(Q-\alpha Q_{0}\right)}{\bar{F}\left(Q-\alpha Q_{0}\right)}<\frac{f\left(Q-\alpha Q_{0}\right)}{\frac{w-s}{p-s} \bar{F}(\underline{x})} .
$$

Furthermore, we have

$$
\begin{aligned}
& \frac{f\left(Q-\alpha Q_{0}\right)}{\bar{F}\left(Q-\alpha Q_{0}\right)}<\frac{f\left(Q-\alpha Q_{0}\right)}{\frac{w-s}{p-s} \bar{F}(\underline{x})} \Leftrightarrow \bar{F}\left(Q-\alpha Q_{0}\right)>\frac{w-s}{p-s} \bar{F}(\underline{x}) \\
& \Leftrightarrow \bar{F}\left(Q-\alpha Q_{0}\right)>\frac{r p F}{r}(Q)+((1-r) p-s) \bar{F}\left(Q-\alpha Q_{0}\right) \\
& \Leftrightarrow(p-s) \bar{F}\left(Q-\alpha Q_{0}\right)>r p \bar{F}(Q)+((1-r) p-s) \bar{F}\left(Q-\alpha Q_{0}\right) \Leftrightarrow r p \bar{F}\left(Q-\alpha Q_{0}\right)>r p \bar{F}(Q) \\
& \Leftrightarrow Q-\alpha Q_{0}<Q
\end{aligned}
$$
$\frac{\partial Q}{\partial \alpha}>0$.

It is obvious that the last inequality holds. Therefore, $\frac{w-s}{p-s} h(\underline{x})-\frac{f\left(Q-\alpha Q_{0}\right)}{\bar{F}(\underline{x})}<0$ and 
Applying the implicit function theorem, the first derivative of Equation (5) with regard to $Q_{0}$ is

$$
-r p f(Q) \frac{\partial Q}{\partial Q_{0}}+(w-s) f(\underline{x}) \frac{\partial \underline{x}}{\partial Q_{0}}-((1-r) p-s) f\left(Q-\alpha Q_{0}\right)\left(\frac{\partial Q}{\partial Q_{0}}-\alpha\right)=0 .
$$

Plugging $\frac{\partial x}{\partial Q_{0}}=\frac{(w-s) \frac{\partial Q}{\partial Q_{0}}+p-\alpha((1-r) p-s)}{p-s}$ into the equation above, and after some simple derivation, we have

$$
\frac{\partial Q}{\partial Q_{0}}=-\frac{\alpha((1-r) p-s) f\left(Q-\alpha Q_{0}\right)+\frac{(w-s)((1-\alpha(1-r)) p+\alpha s)}{p-s} f(\underline{x})}{\frac{(w-s)^{2}}{p-s} f(\underline{x})-r p f(Q)-((1-r) p-s) f\left(Q-\alpha Q_{0}\right)} .
$$

It is straightforward to verify that

$$
\alpha((1-r) p-s) f\left(Q-\alpha Q_{0}\right)+\frac{(w-s)((1-\alpha(1-r)) p+\alpha s)}{p-s} f(\underline{x})>0 .
$$

Therefore, we have $\frac{\partial Q}{\partial Q_{0}}>0$.

Proof of Proposition 2. The first derivative of $\underline{x}$ with regard to $w$ is given as $\frac{\partial \underline{x}}{\partial w}=\frac{Q}{p-s}+$ $\frac{w-s}{p-s} \frac{\partial Q}{\partial w}$.

First, we obtain the first derivative of Equation (6) with regard to $w$. By applying the implicit function theorem, we have

$$
-r p f(Q) \frac{\partial Q}{\partial w}-((1-r) p-s) f\left(Q-\alpha Q_{0}\right) \frac{\partial Q}{\partial w}-\bar{F}(\underline{x})+(w-s) f(\underline{x}) \frac{\partial \underline{x}}{\partial w}=0 .
$$

Plugging $\frac{\partial x}{\partial w}=\frac{Q}{p-s}+\frac{w-s}{p-s} \frac{\partial Q}{\partial w}$ into the above equation, we have

$$
\frac{\partial Q}{\partial w}=\frac{\bar{F}(\underline{x})\left(1-Q h(\underline{x}) \frac{w-s}{p-s}\right)}{\frac{(w-s)^{2}}{p-s} f(\underline{x})-r p f(Q)-((1-r) p-s) f\left(Q-\alpha Q_{0}\right)} .
$$

Taking the first-order derivative of Equation (10) with regard to $w$, we have

$$
\frac{\partial \mathrm{E} \pi_{m}}{\partial w}=Q+(w-c) \frac{\partial Q}{\partial w}-(1-\eta) Q F(\underline{x})-(1-\eta) w \frac{\partial Q}{\partial w} F(\underline{x})-(1-\eta) L f(\underline{x}) \frac{\partial \underline{x}}{\partial w}-\eta(p-s) F(\underline{x}) \frac{\partial \underline{x}}{\partial w} .
$$

This can be simplified as

$$
\frac{\partial \mathbf{E} \pi_{m}}{\partial w}=\left(K_{1}-c+s \eta\right) \frac{\partial Q}{\partial w} .
$$

where

$$
K_{1}=\frac{Q \bar{F}(\underline{x})\left(1-\frac{L}{p-s}(1-\eta) h(\underline{x})\right)}{\frac{\partial Q}{\partial w}}+\bar{F}(\underline{x})\left(w-s \eta-\frac{w-s}{p-s}(1-\eta) \operatorname{Lh}(\underline{x})\right) .
$$

Plugging $\frac{\partial Q}{\partial w}$ into $K_{1}$, we have

$$
\begin{aligned}
K_{1}= & \frac{Q\left(1-\frac{1-\eta}{p-s} \operatorname{Lh}(\underline{x})\right)\left(\frac{(w-s)^{2}}{p-s} f(\underline{x})-r p f(Q)-((1-r) p-s) f\left(Q-\alpha Q_{0}\right)\right)}{1-\frac{w-s}{p-s} \operatorname{Qh}(\underline{x})} \\
& +\bar{F}(\underline{x})\left((w-\eta s)-\frac{w-s}{p-s}(1-\eta) \operatorname{Lh}(\underline{x})\right)
\end{aligned}
$$


The above equation can be rewritten as

$$
K_{1}=\frac{G_{1}+G_{2}}{1-\frac{w-s}{p-s} Q h(\underline{x})},
$$

where

$$
\begin{gathered}
G_{1}=Q\left(1-\frac{1-\eta}{p-s} \operatorname{Lh}(\underline{x})\right)\left(\frac{(w-s)^{2}}{p-s} f(\underline{x})-r p f(Q)-((1-r) p-s) f\left(Q-\alpha Q_{0}\right)\right), \\
G_{2}=\left(\bar{F}(\underline{x})-\frac{w-s}{p-s} \operatorname{Qh}(\underline{x}) \bar{F}(\underline{x})\right)\left((w-\eta s)-\frac{w-s}{p-s}(1-\eta) \operatorname{Lh}(\underline{x})\right) .
\end{gathered}
$$

Furthermore, after some calculations, we have

$$
G_{1}+G_{2}=\Re_{1}-\Re_{2}
$$

where

$$
\begin{gathered}
\Re_{1}=\bar{F}(\underline{x})\left(w-\eta s-\frac{w-s}{p-s}(1-\eta)(L+s Q) h(\underline{x})\right), \\
\Re_{2}=Q\left(1-\frac{1-\eta}{p-s} \operatorname{Lh}(\underline{x})\right)\left(r p f(Q)+((1-r) p-s) f\left(Q-\alpha Q_{0}\right)\right) .
\end{gathered}
$$

Therefore, the wholesale price that maximizes the manufacturer's expected profit must satisfy the FOC condition; i.e., $\frac{\partial \mathrm{E} \pi_{m}}{\partial w}=0$. Accordingly, we have

$$
\frac{\Re_{1}-\Re_{2}}{1-\frac{w-s}{p-s} Q h(\underline{x})}-c+s \eta=0 .
$$

\section{References}

1. Keys, T.; Malnight, T. The Exploding Business of Bartering. Harvard Business Review. Available online: https://hbr.org/2012/0 $9 /$ the-exploding-business-of-bart (accessed on 1 September 2021).

2. Hua, G.; Zhang, Y.; Cheng, T.; Wang, S.; Zhang, J. The newsvendor problem with barter exchange. Omega 2020, 92, 102149. [CrossRef]

3. Guriev, S.; Kvassov, D. Barter for price discrimination. Int. J. Ind. Organ. 2004, 22, 329-350. [CrossRef]

4. Sullivan, A.M.; Sheffrin, S.M. Economics: Principles in Action; Pearson Prentice Hall: Hoboken, NJ, USA, $2003 ;$ p. 243.

5. Anderson, R.; Ashlagi, I.; Gamarnik, D.; Kanoria, Y. Efficient dynamic barter exchange. Oper. Res. 2017, 65, 1446-1459. [CrossRef]

6. Chang, H.L.; Rhee, B.D. Trade credit for supply chain coordination. Eur. J. Oper. Res. 2011, 214, $136-146$.

7. Phan, D.A.; Vo, T.L.H.; Lai, A.N. Supply chain coordination under trade credit and retailer effort. Int. J. Prod. Res. 2019, 57, 2642-2655. [CrossRef]

8. Yang, C.; Wu, D.; Fang, W. Capital-constrained bi-objective newsvendor model with risk-averse preference and bankruptcy threshold. Ind. Manag. Data Syst. 2019, 120, 406-424. [CrossRef]

9. Garcia-Marin, A.; Justel, S.; Schmidt-Eisenlohr, T. Trade Credit, Markups, and Relationships. FRB Int. Financ. Discuss. Pap. 2020, 2020, 1303. [CrossRef]

10. Plank, R.E.; Reid, D.A.; Bates, F. Barter: An alternative to traditional methods of purchasing. Int. J. Purch. Mater. Manag. 1994, 30, 51-57. [CrossRef]

11. Erridge, A.; Zhabykenov, D. The role of purchasing in countertrade. Eur. J. Purch. Supply Manag. 1998, 4, 97-107. [CrossRef]

12. Zhang, B.; Wei, L.; Chen, M. Implications of barter exchange and decision biases in a pull contract. Int. Trans. Oper. Res. 2021, 2021, 13057. [CrossRef]

13. Marin, D.; Schnitzer, M. The economic institution of international barter. Econ. J. 2002, 112, 293-316. [CrossRef]

14. Noguera, J.; Linz, S.J. Barter, credit and welfare: A theoretical inquiry into the barter phenomenon in Russia. Econ. Transit. 2006, 14, 719-745. [CrossRef]

15. Mpinganjira, M. An empirical investigation into difficulties associated with barter trading: A practioners' perspective. Afr. J. Bus. Manag. 2011, 5, 1085-1092.

16. Melis, C.; Guidici, E. Is barter a strategic response to the global capitalist crisis? In Capitalism and the Social Relationship; Palgrave Macmillan: London, UK, 2014; pp. 265-277. 
17. Ye, S.; Viswanathan, S.; Hann, I.H. The Value of Reciprocity in Online Barter Markets: An Empirical Investigation. MIS Q. 2018, 42, 521-549. [CrossRef]

18. Fujishige, S.; Yang, Z. Barter markets, indivisibilities, and Markovian core. Bull. Econ. Res. 2021, 2021, 12279. [CrossRef]

19. Lee, Y.W.; Stowe, J.D. Product risk, asymmetric information, and trade credit. J. Financ. Quant. Anal. 1993, 28, 285-300. [CrossRef]

20. Liao, H.-C.; Tsai, C.-H.; Su, C.-T. An inventory model with deteriorating items under inflation when a delay in payment is permissible. Int. J. Prod. Econ. 2000, 63, 207-214. [CrossRef]

21. Summers, B.; Wilson, N. Trade credit and customer relationships. Manag. Decis. Econ. 2003, 24, 439-455. [CrossRef]

22. Gupta, D.; Wang, L. A stochastic inventory model with trade credit. Manuf. Serv. Oper. Manag. 2009, 11, 4-18. [CrossRef]

23. Giannetti, M.; Burkart, M.; Ellingsen, T. What you sell is what you lend? Explaining trade credit contracts. Rev. Financ. Stud. 2011, 24, 1261-1298. [CrossRef]

24. Chen, X.; Wang, A. Trade credit contract with limited liability in the supply chain with budget constraints. Ann. Oper. Res. 2012, 196, 153-165. [CrossRef]

25. Klapper, L.; Laeven, L.; Rajan, R. Trade credit contracts. Rev. Financ. Stud. 2012, 25, 838-867. [CrossRef]

26. Luo, J.; Zhang, Q. Trade credit: A new mechanism to coordinate supply chain. Oper. Res. Lett. 2012, 40, 378-384. [CrossRef]

27. Zhong, Y.G.; Zhou, Y.W. Improving the supply chain's performance through trade credit under inventory-dependent demand and limited storage capacity. Int. J. Prod. Econ. 2013, 143, 364-370. [CrossRef]

28. Zhang, Q.; Dong, M.; Luo, J.; Segerstedt, A. Supply chain coordination with trade credit and quantity discount incorporating default risk. Int. J. Prod. Econ. 2014, 153, 352-360. [CrossRef]

29. Dass, N.; Kale, J.R.; Nanda, V. Trade credit, relationship-specific investment, and product market power. Rev. Financ. 2015, 19, 1867-1923. [CrossRef]

30. Chen, Z.; Yu, H. Trade credit policy of supply chain with oversupply. In Proceedings of the 2017 29th Chinese Control and Decision Conference (CCDC), Chongqing, China, 28-30 May 2017; pp. 3396-3401.

31. Yang, H.L.; Zhuo, W.Y.; Shao, L.S.; Talluri, S. Mean-variance analysis of wholesale price contracts with a capital-constrained retailer: Trade credit financing vs. bank credit financing. Eur. J. Oper. Res. 2021, 294, 525-542. [CrossRef]

32. Wang, P.; Bi, G.; Yan, X. Optimal two-level trade credit with credit-dependent demand in a newsvendor model. Int. Trans. Oper. Res. 2021, 2021, 13024. [CrossRef]

33. Ferrando, A.; Mulier, K. Do firms use the trade credit channel to manage growth? J. Bank. Financ. 2013, 37, 3035-3046. [CrossRef]

34. Devalkar, S.K.; Krishnan, H. The impact of working capital financing costs on the efficiency of trade credit. Prod. Oper. Manag. 2019, 28, 878-889. [CrossRef]

35. Liu, B.; Wang, Y.; Shou, Y. Trade credit in emerging economies: An interorganizational power perspective. Ind. Manag. Data Syst. 2020, 120, 768-783. [CrossRef]

36. Kouvelis, P.; Zhao, W. The newsvendor problem and price-only contract when bankruptcy costs exist. Prod. Oper. Manag. 2011, 20, 921-936. [CrossRef]

37. Yang, S.A.; Birge, J.R. Trade credit, risk sharing, and inventory financing portfolios. Manag. Sci. 2018, 64, 3667-3689. [CrossRef]

38. Wu, D.; Zhang, B.; Baron, O. A trade credit model with asymmetric competing retailers. Prod. Oper. Manag. 2019, $28,206-231$. [CrossRef]

39. Chen, X.; Wan, G. The effect of financing on a budget-constrained supply chain under wholesale price contract. Asia-Pac. J. Oper. Res. 2011, 28, 457-485. [CrossRef]

40. Battistella, L.M.; Hynes, N. Something new under the sun? A case study of modern italian barter systems. J. Appl. Bus. Econ. 2019, 21, 27-50. 